\title{
OPTICAL FEATURES OF InAs QUANTUM DOTS-IN-A-WELL STRUCTURES
}

\author{
R. Nedzinskas ${ }^{\text {a }}$, B. Čechavičius ${ }^{\text {a }}$, A. Rimkus ${ }^{\text {a }}$, J. Kavaliauskas ${ }^{\text {a }}$, G. Valušis ${ }^{\text {a }}$, \\ L.H. Li ${ }^{b}$, and E.H. Linfield ${ }^{b}$ \\ ${ }^{a}$ Semiconductor Physics Institute, Center for Physical Sciences and Technology, A. Goštauto 11, LT-01108 Vilnius, Lithuania \\ E-mail: ramunas@pfi.lt \\ ${ }^{\mathrm{b}}$ School of Electronic and Electrical Engineering, University of Leeds, Leeds LS2 9JT, United Kingdom
}

Received 18 November 2013; accepted 4 December 2013

\begin{abstract}
Electronic energy structure and features of optical interband transitions of InAs quantum dots-in-a-well structures are studied via photoreflectance $(\mathrm{PR})$ and temperature-dependent photoluminescence $(\mathrm{PL})$ spectroscopy. InAs dots were grown with and without InGaAs capping layer and embedded in GaAs/AlAs quantum wells. Experimental results revealed that the $5 \mathrm{~nm}$ thick InGaAs capping layer significantly improves PR and PL signal intensity. Moreover, a shift of the quantum dot ground-state optical transition to lower energy by about $120 \mathrm{meV}$ was observed. The red-shift of the ground-state transition is associated mainly with an increase of dot size and decrease of strain within quantum dots. Furthermore, the origin of PL intensity quenching with temperature is discussed in terms of electronic energy structure revealed from PR spectra and calculations performed within effective mass approximation.
\end{abstract}

Keywords: quantum dots, dots-in-a-well, photoreflectance spectroscopy, photoluminescence

PACS: 81.07.Ta; 73.21.La; 78.67.Hc

\section{Introduction}

Semiconductor quantum dots (QDs) owing to their unique atomic-like quantum confinement are particularly attractive both for fundamental research and applications in optoelectronic devices such as QD infrared photodetectors (QDIPs). Recently, an advanced QDIP structure was implemented by covering selfassembled InAs/GaAs QDs with a strain-relieving InGaAs layer [1]. This dots-in-a-well (DWELL) design is based on optical transitions between dot and quantum well (QW) states and offers additional possibility to vary transition energy by adjusting QW width and composition. To optimize operation of such novel devices it is essential to know in detail their optical properties and electronic structure. This information can be obtained by photoluminescence (PL) and modulated reflectance spectroscopy, in particular, by photoreflectance (PR) technique [2, 3].

This work presents a comparative spectroscopic study of self-assembled InAs QDs grown with and without InGaAs capping layer and embedded in GaAs/ AlAs QWs. Electronic states and optical interband transitions of these DWELL structures are studied using PR and temperature-dependent PL methods.

\section{Sample growth and experiment}

The structures studied were grown by molecular beam epitaxy (MBE) on a semi-insulating (100) GaAs substrate and composed of InAs QDs (10/15 periods) embedded in GaAs 30/35 nm thick wells and surrounded by $5 \mathrm{~nm}$ thick AlAs barriers. StranskiKrastanow QDs were grown by depositing 2.4 monolayers of InAs with (sample L442) or without (sample L444) $5 \mathrm{~nm}$ thick $\mathrm{In}_{0.15} \mathrm{Ga}_{0.85}$ As strain-relieving cap layer. Thereby, two different DWELL structures were formed: InAs/GaAs/AlAs (L444) and InAs/ InGaAs/GaAs/AlAs (L442). Lenslike QDs having $\sim 5 \mathrm{~nm}$ height and $\sim 20 \mathrm{~nm}$ diameter were doped with one electron per dot.

Room temperature PR measurements were performed using HeNe $(632.8 \mathrm{~nm})$ or DPSS $(473 \mathrm{~nm})$ laser modulated at $650 \mathrm{~Hz}$. PL experiments were carried out in the temperature range of 4.2-300 K. Samples were mounted in a closed-cycle He cryostat and excited with DPSS laser $(532 \mathrm{~nm})$. The power density was between $2-500 \mathrm{~W} / \mathrm{cm}^{2}$ (owing to various neutral filters used). Depending on the wavelength range, PR and PL signals were detected with Si or InGaAs photodetector using a conventional lock-in system. 


\section{Results and discussion}

Room temperature PR and PL spectra for the samples L444 and L442 are shown in Fig. 1. Three major sets of features related to various excitonic transitions (indicated by numbers) can be identified. In the low photon energy range of $0.9-1.25 \mathrm{eV}, \mathrm{PR}$ and PL spectra exhibit several broadened features due to QD groundstate (GS) and excited-state (ES) transitions. Further, in the energy range between 1.25-1.42 eV, sharp and intensive PR lines (5-7) for the L442 sample correspond to GS and ES transitions in the InAs/InGaAs binary quantum well (bi-QW) formed by InAs wetting layer (WL) and InGaAs cap. In case of sample L444, the PR spectrum shows two lines $(4,5)$ related to InAs/GaAs WL/QW. The high energy features above the bandgap of $\mathrm{GaAs}(1.42 \mathrm{eV})$ are ascribed to interband transitions in a wide GaAs/AlAs QW, which are superimposed by Franz-Keldysh oscillations from the GaAs buffer layer.

To determine transition energies and broadening parameters, recorded PR spectra were fitted to the first derivative of a Lorentzian-type function [2, 3]. In the low photon energy range, the following QD-related optical transitions were estimated for the InGaAs-capped structure L442: GS(1) $=0.951 \mathrm{eV}, \mathrm{ES}_{1}(2)=1.008 \mathrm{eV}$, $\mathrm{ES}_{2}(3)=1.062 \mathrm{eV}$, and $\mathrm{ES}_{3}(4)=1.152 \mathrm{eV}$. Heavy- and light-hole related transitions in the InAs/InGaAs biQW were at $11 \mathrm{H}(5)=1.250 \mathrm{eV}$ and $11 \mathrm{~L}(6)=1.358 \mathrm{eV}$. Optical transitions in InAs QDs for the uncapped structure L444 were recorded at $\mathrm{GS}(1)=1.073 \mathrm{eV}$, $\mathrm{ES}_{1}(2)=1.128 \mathrm{eV}$, and $\mathrm{ES}_{2}(3)=1.190 \mathrm{eV}$, whereas higher energy excitonic transitions in InAs/GaAs WL/QW appeared at $11 \mathrm{H}(4)=1.321 \mathrm{eV}$ and $11 \mathrm{~L}(5)=1.398 \mathrm{eV}$.

On the basis of PR and PL data it was evaluated that the presence of the InGaAs cap layer induced a redshift by about $120 \mathrm{meV}$ of GS optical transitions in InAs QDs. This significant red-shift could be attributed to the increase in dot size owing to the strain-driven phase segregation of the hetero-capping alloy [4]. To estimate the actual In content in the $\mathrm{In}_{x} \mathrm{Ga}_{1-x}$ As cap layer, calculations of the energy and transition probability for heavy- $(11 \mathrm{H})$ and light-hole $(11 \mathrm{~L})$ related optical transitions (Fig. 1) were performed under the effective mass approximation. Combining calculation results along with $\mathrm{PR}$ and $\mathrm{PL}$ data for the complex InGaAs/GaAs/AlAs QW, an actual value of $x=0.13$ for the $\operatorname{In}_{x} \mathrm{Ga}_{1-x}$ As capping layer was deduced. Thereby, a red-shift of QD ground-state interband transitions for the capped DWELL structure can be partly ascribed to the increase (variation) of effective QD size (shape) owing to decomposition of the InGaAs cap layer during MBE growth.

To get a deeper insight into thermal processes, temperature-dependent PL spectra of QD structures were

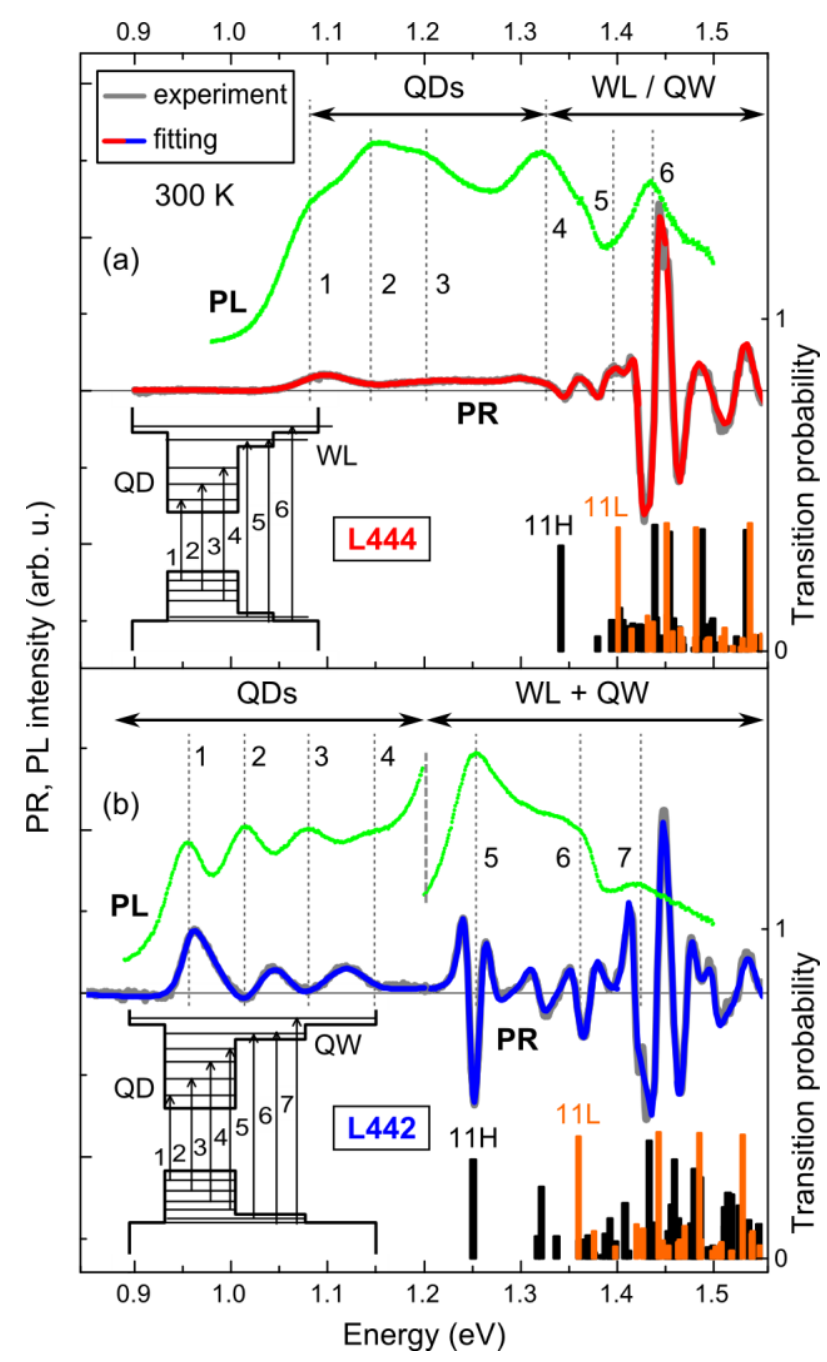

Fig. 1. Room temperature PR and PL spectra for DWELL structure (a) without (sample L444) and (b) with (sample L442) InGaAs cap layer. The position and amplitude of vertical bars represent calculated optical transition energies and intensities, respectively. Insets: Schematic band diagrams of the nanostructures studied along with experimentally revealed interband transitions (numbered).

measured. Both samples show a GS transition shift toward lower energies with increase in temperature (Fig. 2). Also, the PL linewidth is much narrower for the InGaAs-capped sample, owing to a more uniform size distribution of QDs.

Peak energy and full width at half maximum (FWHM) parameter of the InAs QD ground-state PL Gaussian line demonstrate very different temperature behaviour for DWELL structures with and without InGaAs layer (Fig. 3). For uncapped sample L444, the anomalous reduction of FWHM parameter at $\sim 170 \mathrm{~K}$ is accompanied by a sudden red-shift of the emission peak, which is typical of InAs/GaAs QDs. Usually, this behaviour can be explained by thermally activated carrier escape and retrapping in QDs [5, 6]. When 


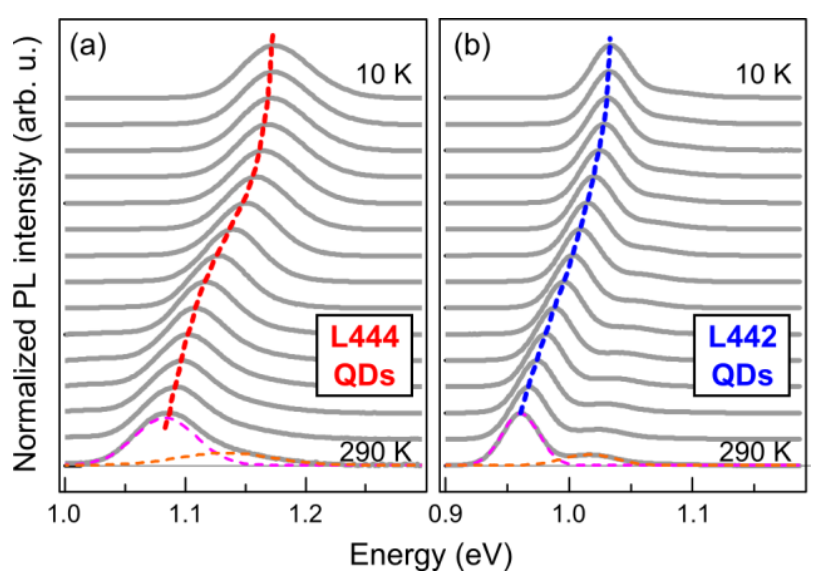

Fig. 2. Temperature-dependent PL spectra (normalized) of InAs QDs for DWELL structure (a) without (sample L444) and (b) with (sample L442) InGaAs cap layer. Each PL band was analysed with two Gaussian lines corresponding to GS and ES.

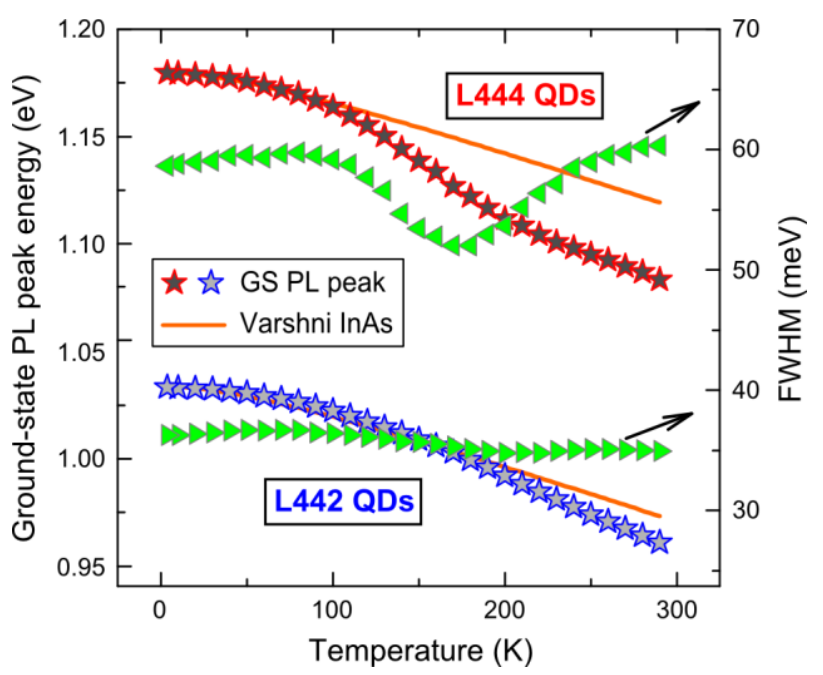

Fig. 3. Peak energy and FWHM of the ground-state PL Gaussian line versus temperature for DWELL structure without (sample L444; top) and with (sample L442; bottom) InGaAs cap layer. Temperature dependence of GS peak energy for both DWELL structures is compared to the energy gap shift of bulk InAs (for convenience Varshni curves are shifted along $y$ axis).

the temperature exceeds $200 \mathrm{~K}$, electron-phonon scattering becomes important, thus a strong increase in FWHM with temperature is observed. The shift of PL band in a high temperature region becomes similar to that of a bulk InAs bandgap (Varshni curves, Fig. 3).

The situation is different with the InGaAs-capped sample L442, where FWHM parameter exhibits almost no reduction as the temperature rises and the peak position of PL shifts without any obvious kink almost following the bandgap shift of bulk InAs. This suggests that the use of the InGaAs cap layer yields much smaller QD size dispersion, which is manifested by indistinct thermal transferring and redistribution of carriers in the 4.2-300 K temperature range. Hereinafter, thermal quenching of PL intensity in InAs QDs is disputed.

The impact of temperature on integrated PL intensity for the GS excitonic transitions in QD structures studied is given in Fig. 4. Experimental data show that for both samples a decay of the PL intensity exhibit two different slopes - one in the intermediate (120$210 \mathrm{~K})$ and another in the high $(210-290 \mathrm{~K})$ temperature regions. This thermal quenching of InAs QDs was analysed in terms of integrated PL intensity $I(T)$ described by the Arrhenius-type expression:

$$
I=I_{0} /\left[1+a \exp \left(-E_{\mathrm{a}} / k T\right)+b \exp \left(-E_{\mathrm{b}} / k T\right)\right] \cdot(1)
$$

Equation (1) takes into account two thermal quenching processes that have $E_{\mathrm{a}}$ and $E_{\mathrm{b}}$ activation energies for lower and higher temperature regions, respectively. It was estimated that a relatively weak decrease of the PL intensity between $120-210 \mathrm{~K}$ corresponds to activation energies $E_{\mathrm{a}}$ of $62 \mathrm{meV}$ (sample L444) and $86 \mathrm{meV}$ (L442), whereas a sharp drop above $\sim 210 \mathrm{~K}$ corresponds to $E_{\mathrm{b}}$ of $269 \mathrm{meV}$ (L444) and $301 \mathrm{meV}$ (L442).

In the high temperature region, activation energies $E_{\mathrm{b}}$ match the total barrier heights of $\Delta E=E_{\mathrm{WL}}-E_{\mathrm{OD}}=268 \mathrm{meV}$ (L444) and $\Delta E=E_{\mathrm{QW}}-E_{\mathrm{QD}}=299 \mathrm{meV}$ (L442) deduced from PR

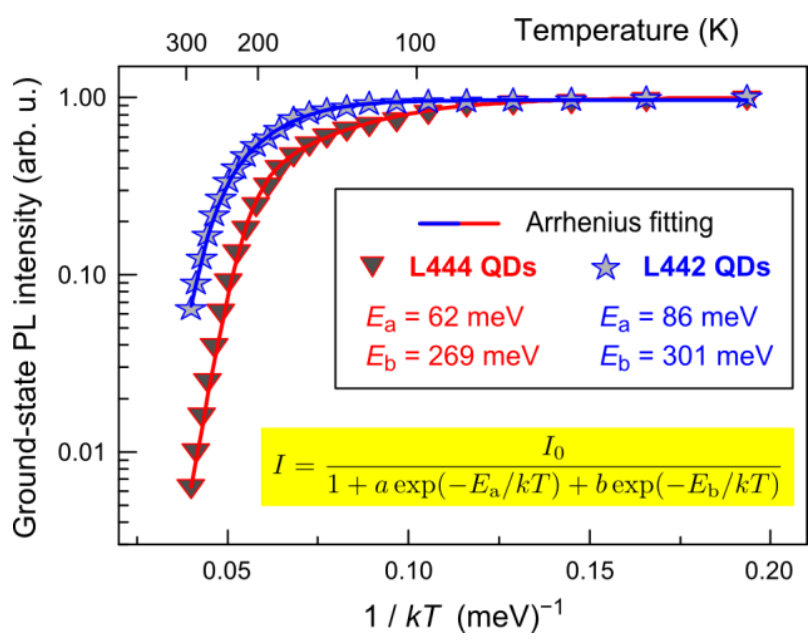

Fig. 4. Integrated intensity of the the InAs QD groundstate PL emission band (normalized) as a function of the temperature for the DWELL structure without (L444; triangles) and with (sample L442; stars) InGaAs cap layer. The least-square method fitting was performed using the Arrhenius-type function. 
data (see Fig. 1). This implies that at high temperatures thermal quenching of PL intensity from QDs is probably caused by the excitons escaping from the QD bound-state to InAs WL (L444) or InGaAs QW (L442), as was discussed in Ref. [6].

However, in the intermediate temperature region the PL intensity decay mechanism described by the smaller activation energy $E_{\mathrm{a}}$ is less evident. It was suggested that this thermal quenching could be governed by extrinsic processes connected to the presence of defects in the InGaAs cap layer and/or in proximity of QDs 沛. On the other hand, within the error of calculations the derived activation energies $E_{\mathrm{a}}$ are close to one half of $\Delta E=E_{\mathrm{GaAs} \mathrm{QW}}-E_{\mathrm{WL}}=99 \mathrm{meV}$ (sample L444) and $\Delta E=E_{\mathrm{GaAs} \mathrm{QW}}-E_{\mathrm{InGaAs} \mathrm{QW}}=170 \mathrm{meV}$ (L442) obtained from PR spectra. Therefore, thermal quenching of PL intensity from QDs at intermediate temperatures can be presumably caused by the reduced carrier flow into QDs due to the thermal escape of electronhole pairs from WL (sample L444) or from InGaAs QW (L442) to GaAs/AlAs QW [6].

\section{Conclusions}

Spectroscopic photoreflectance and temperaturedependent photoluminescence results show that the use of an InGaAs cap layer shifts the InAs quantum dot ground-state interband transition to lower energy by $\sim 120 \mathrm{meV}$, while maintaining strong quantization of the electronic states and significantly improving emission from dots at room temperature. The redshift of the ground-state transition is attributed to an increase of dot size and decrease of strain within quantum dots. Results obtained from our study validate a pathway to shift the photodetectivity peak towards longer wavelengths in InAs quantum dot infrared photodetectors.

\section{Acknowledgements}

Current research was funded by a grant (No. MIP071/2012) from the Research Council of Lithuania.

\section{References}

[1] J.R. Andrews, S.R. Restaino, S. Teare, Y.D. Sharma, W.-Y. Jang, T.E. Vandervelde, J.S. Brown, A. Reisinger, M. Sundaram, S. Krishna, and L. Lester, IEEE Trans. Electron Dev. 58(7), 2022 (2011), http://dx.doi.org/10.1109/ TED.2011.2140374

[2] B. Cechavičius, J. Kavaliauskas, G. Krivaite, D. Seliuta, G. Valušis, M.P. Halsall, M.J. Steer, and P. Harrison, J. Appl. Phys. 98(2), 023508 (2005), http://link.aip.org/link/doi/10.1063/1.1978970

[3] R. Nedzinskas, B. Cechavičius, J. Kavaliauskas, V. Karpus, D. Seliuta, V. Tamošiūnas, G. Valušis, G. Fasching, K. Unterrainer, and G. Strasser, I, Appl. Phys. 106(6), 064308 (2009), http://link.aip. org/link/doi/10.1063/1.3212980

[4] M.V. Maximov, A.F. Tsatsul'nikov, B.V. Volovik, D.S. Sizov, Yu.M. Shernyakov, I.N. Kaiander, A.E. Zhukov, A.R. Kovsh, S.S. Mikhrin, V.M. Ustinov, Zh.I. Alferov, R. Heitz, V.A. Shchukin, N.N. Ledentsov, D. Bimberg, Yu.G. Musikhin, and W. Neumann, Phys. Rev. B 62(24), 16671 (2000), http://link.aps.org/doi/10.1103/PhysRevB.62.16671

[5] S. Sanguinetti, M. Henini, M. Grassi Alessi, M. Capizzi, P. Frigeri, and S. Franchi, Phys. Rev. B 60(11), 8276 (1999), http://link.aps.org doi/10.1103/PhysRevB.60.8276

[6] T.V. Torchynska, J.L. Casas Espinola, L.V. Borkovska, S. Ostapenko, M. Dybiec, O. Polupan, N.O. Korsunska, A. Stintz, P.G. Eliseev, and K.J. Malloy, J. Appl. Phys. 101(2), 024323 (2007), http://link.aip.org/link/doi/10.1063/1.2427105

[7] L. Seravalli, M. Minelli, P. Frigeri, S. Franchi, G. Guizzetti, M. Patrini, T. Ciabattoni, and M. Geddo, J. Appl. Phys. 101(2), 024313 (2007), http://link.aip.org/link/doi/10.1063/1.2424523

\title{
InAs KVANTINIŲ TAŠKŲ KVANTINĖSE DUOBĖSE OPTINĖS SAVYBĖS
}

\author{
R. Nedzinskas ${ }^{\text {a }}$, B. Čechavičius ${ }^{\text {a }}$, A. Rimkus ${ }^{\text {a }}$, J. Kavaliauskas ${ }^{\text {a }}$, G. Valušis ${ }^{\text {a }}$, L.H. Li ${ }^{\text {b }}$, E.H. Linfield ${ }^{\text {b }}$ \\ a Fiziniu ir technologijos moksly centro Puslaidininkiu fizikos institutas, Vilnius, Lietuva \\ ${ }^{\mathrm{b}}$ Lidso universitetas, Lidsas, Jungtine Karalystè
}

\section{Santrauka}

Fotoatspindžio ir fotoliuminescencijos metodais 4,2$300 \mathrm{~K}$ temperatūrų intervale ištirti InAs kvantinių taškų, iterptų $\mathfrak{i}$ GaAs/AlAs kvantines duobes, tarpjuostinių optinių šuoliųpobūdis ir prigimtis. Atskleistasịtempimus sumažinančiojo InGaAs sluoksnio poveikis kvantinių taškų optinèms savybèms ir elektroninei sandarai: apie
$120 \mathrm{meV}$ siekiantis energijų tarpo tarp pagrindiniu kvantinio taško būsenų sumažèjimas bei šviesos emisijos sustiprejjimas kambario temperatūroje. Daroma prielaida, jog šiuos efektus sukelia InAs kvantinio taško padidejimas ir formos pakitimas dengiančiojo InGaAs sluoksnio auginimo metu. 